\title{
SOCIAL AND PSYCHOLOGICAL THERAPY EFFICIENCY FOR WOMEN, VICTIMS OF DOMESTIC VIOLENCE
}

\author{
ВИЗНАЧЕННЯ ЕФЕКТИВНОСТІ СОЦАЛЬНО-ПСИХОЛОГІЧНОЇ ТЕРАПІЇ \\ У РОБОТІ 3 ЖІНКАМИ, ЯКІ СТАЛИ ЖЕРТВАМИ НАСИЛЛЯ В СІМ'Ї
}

UDC 364.63-785.14-787.3-

055.2(477+569.4)

DOI https://doi.org/10.32843/2663-

5208.2020.18.1.24

\section{Surhova S.Yu.}

Ph.D., Associate Professor

at the Department of Social Work,

Management and Pedagogy

Petro Mohyla Black Sea National

University

\section{Faichuk O.L.}

Ph.D., Associate Professor at the Department of Social Work, Management and Pedagogy Petro Mohyla Black Sea National University

\section{Tsvetkov M.}

Social Worker, Therapist Regional Center for Therapy and Prevention of Domestic Violence
The article highlights the issue of the effectiveness of socio-psychological therapy when working with women who have become victims of domestic violence. The experience of social work with this category of women in Ukraine and Israel is analyzed. The main criteria for the effectiveness of socio-psychological therapy have been determined: awareness, emotional stability, the ability to use internal and external resources, and the effectiveness of functioning. The advantages of individual and group forms of therapy when working with women are analyzed.

In the course of the study, a psychodynamic approach was used in individual therapy using elements of cognitive-behavioral therapy, narrative and imago therapy. In group work, women received relevant information and discussed it. At the end of the experiment, the effectiveness of therapy was assessed. Using the methods of mathematical data processing, the effectiveness of socio-psychological therapy in working with women who have become victims of domestic violence has been proven, namely, there is a significant increase in all criteria of therapy, its effectiveness is proved regardless of the form of its implementation (individual or group therapy). The study does not exhaust all aspects of this problem. Further socio-psychological searches include the introduction of the investigated sociopsychological therapy in the activities of centers of social and psychological assistance in Ukraine, followed by monitoring of its effectiveness when working with women victims of domestic violence. The results of the study can be used for practical purposes by social workers and psychologists of crisis and therapeutic centers, students studying in relevant specialties, government workers in planning and organizing the work of relevant institutions in Ukraine, for research purposes by scientists who study the problem of violence in families.

Key words: socio-psychological therapy, protocol of socio-psychological support, regional center for therapy and prevention of domestic violence, social work, domestic violence.

у статті розглядається питання ефективності соціально-психологічної терапіі у роботі з жінками, які стали жертвами насилля в сім'ї. Проаналізовано досвід соціальної роботи з цією категорією жінок в Україні та Ізраїлі. Визначено основні критерії есрективності соціально-психологічної терапії: усвідомленість, емоційна стабільність, здатність до користування внутрішніми та зовнішніми ресурсами, ефективність ффункціонування. Проаналізовано переваги індивідуальної та групової фрорм терапії у роботі з жінками.

У процесі дослідження під час індивідуальної терапії використовувався психодинамічний підхід із застосуванням елементів когнітивно-поведінкової терапії, наративної терапії та імаготерапії. В груповій роботі жінки отримували релевантну інформацію й обговорювали іï. Наприкінці експерименту було проведено оцінку ефектииності терапії. За допомогою методів математичної обробки даних доведено есрективність соціально-психологічної терапії у роботі з жінками, які стали жертвами насилля в сім'ї, а саме спостерігаємо значне зростання за всіма критеріями терапії незалежно від форми ії проведення (індивідуальна або групова терапія), що доводить ії ефеективність.

Дослідження не вичерпує всіх аспектів указаної проблеми. Подальші соціально-психологічні пошуки передбачають впровадження досліджуваної соціально-психологічної терапії в діяльність чентрів соціально-психологічної допомоги в Україні з подальшим моніторингом іï ефрективності у роботі з жінками - жертвами сімейного насилля. Результати дослідження можуть бути використані в практичних цілях соціальними працівниками та психологами кризових та терапевтичних центрів, студентами, що навчаються за відповідними спеціальностями, державними працівниками під час планування й устрою роботи відповідних закладів на території України, у дослідницьких цілях науковцями, що вивчають проблему насильства в сім'ях.

Ключові слова: соціально-психологічна терапія, протокол соціально-психологічного супроводу, регіональний чентр терапії і профілактики насилля в сім'ї, соціальна робота, сімейне насилля.
Introduction. The problem of domestic violence is quite widespread in the modern social space and applies to many countries of the world. Violence puts a person in a dependent situation, causing enormous moral damage to society and it is an obstacle to overcoming inequality and observance of human rights. The danger of essence of domestic violence lies in the fact that the manifestations of violence and cruelty not only destroy harmony and cohesion in the family, but also serve as one of the prerequisites of crime in the society as a whole. Therefore, domestic violence is a public problem and needs to be resolved at the state level.

There are numerous scientific theses, which consider some aspects of the investigated theme as follows: L. Sherman and B. Burke, L. Berkowitz, B. Craig, R. Parker and D. Anderson-Fasil, D. Bell, M.A. Gulina and V. Satir.

Aim and Purpose of the Research - to analyse the effectiveness of socio-psychological therapy in the work with women suffered from domestic violence. 
Presentation of the main material. In the process of the research we analyzed both the approaches of various authors to organize assistance to women who have been victims of domestic violence and also practical experience in organizing social work with them in Ukraine and Israel. Thus, in Ukraine, there are regional centers of social and psychological assistance, tasked with assisting in the improving the quality of life and shaping the active life stance of women affected by domestic violence, by ensuring their temporary refuge and provision of a complex of social services (domestic, informational, psychological, socio-pedagogical, social, medical, legal, socio-economic). The principal forms of activity are: provision of consultations, protection of victims' rights, assistance in registration of necessary documents, temporary shelter, psycho-diagnostics, humanitarian aid and etc. However, despite the availability of the declared forms of assistance to women victims of domestic violence in Ukraine, the statistics certify the inefficiency of the existing social work in this direction (according to the sociological survey conducted by the Institute of Demography and Social Research, annually more than $1 \mathrm{mln}$. women suffer from various forms of domestic violence in Ukraine.) This state of things testifies to the ineffectiveness of preventive activity of social services on prevention of domestic violence, so we decided to analyze the existing experience of social therapy in work with women-victims of domestic violence in Israel for its future use in Ukraine.

In Israel there are Centers for Violence Prevention and Control, the clients of which are predominantly women. The essence of work with a woman in such centers is the organization of social support for the victim of domestic violence. The psychological guidance is presently viewed as the support for mentally healthy people who at some stage of their development face certain difficulties. The guidance is regarded as the systematic integrative technology of social and psychological assistance for a personality and as one of the types of social patronage. The significant characteristic of the psychological guidance is to create certain conditions for further transition of an individual to self-help.

In order to test the effectiveness of social and psychological therapy in therapeutic centers for overcoming and preventing domestic violence, in the course of professional cooperation with colleagues at the Regional Center for Therapy and Prevention of Domestic Violence, Beer Sheva (Israel), we conducted a study. The main criteria for the effectiveness of social therapy with women-victims of violence were determined as follows, mindfulness, emotional stability, the ability to use internal and external resources and effectiveness of functioning; additionally, a comparable assessment of the therapy efficiency in groups of women receiving an individual and group therapy was accomplished.

For the work of the Regional Center for Therapy and Prevention of Domestic Violence, (Beer Sheva City) a certain protocol of social and psychological support of women affected by domestic violence is used. It is stipulated primarily by the goals and objectives of a social worker in the professional interaction with the client.

First of all the employees of the center establish relationships of trust with the client, to form open and protected space, where a woman will feel safety, care and will be able to openly speak, describing her vital situation, thoughts and feelings. She must be confident in the professionalism of a social worker who gives her help, to see compassion, and not to feel pressure on her. It is also vitally essential to highlight on the principle of confidentiality of everything she says during the therapy.

One of the most important conditions of maintenance is diagnostics of a threat level. Once the social worker of the Therapeutic Center concludes that a woman is at risk, he stops the conversation and moves to diagnostics with the help of a special questionnaire of danger level. According to the results of the questionnaire, conclusions about the threat level, reported by a woman depicting the possible consequences of inaction, are made. The worker also warns the woman of her personal responsibility for her decision and its consequences. A plan to exit the situation of domestic violence, which includes providing urgent material assistance for the accommodation rent, the shelter for women and their children, going to the police, the court, providing free legal assistance, placement of children to the nursery and secondary schools, etc. It should be noted that the provision of social assistance is handled by the adjacent departments of the Social Assistance Center, where the social worker of the center directs the client additionally. At each stage of the decision-making it is necessary to make sure that a woman realizes her responsibility for the consequences and the risk degree of her choice.

This logically results in the important task when dealing with women -victims of domestic violence, which is the assessment and further search for internal and external resources, which would facilitate a woman's move from the status of the helpless victim, who was firmly fixed by the aggressor in the relationships of violence, to the state where she can independently control her lives and take responsibility for it. Before the start the habilitation or empowerment process (i.e. from the English empowerment - the provision of power - a term that indicates the provision of a person with resources and powers for the successful life adaptation in the society, their 
independent solution of problems, changing their views and, consequently, their life situation), a social worker conducts the search for internal and external resources, which can be the basis for the process. To accomplish this, it is necessary to identify the barriers that interfere with the woman, what she lacks for the efficient use of her reserve. The possible obstacles may comprise the circumstances in which she witnessed domestic violence as a child and she lives with a basic sense of guilt or she is co-dependent by living as a couple with a man who suffers from addiction, etc.

In addition, during the social and psychological support a social worker motivates the client for further therapy, which gives her a chance to get out of the vicious circle of violence, changing the scenario of behavior in the existing couple or in a new one.

During the entire guidance process a social worker draws up a psychological portrait of a client, including all the collected information about a woman, her family, psychological characteristics, mental state, motivational aspect, life circumstances, etc.

All the clients of the therapeutic regional center of Therapy and Prevention of Domestic Violence (hereinafter the center) who have passed the stage of psychological support, receive social-psychological therapy in two possible forms: individual and group. At the same time individual therapy is conducted in each case, while group therapy is added to the course of general therapy under certain conditions, such as the presence of the corresponding group, the recommendations of the therapist, the desire of the client, etc. From our experience individual and group therapy demonstrate high efficiency in the work with victims of domestic violence. But in recent times there is a tendency to unite both forms of therapy in a common comprehensive rehabilitation program.

To participate in our research 73 women between the ages of 19 and 60 were chosen, they appealed to crisis center in the period from September, 1 to October,30 2018, agreed to therapy and passed it without a partner. All the participants received a written salutation, which reported them about the research, its goals and objectives. As a result, 52 women gave voluntary consent to participate in the research, as well as in the processing ofresults, theiranalysisanddiscussionwithinthiswork.

Then the candidates were chosen for the experimental and control groups. All 52 clients proceeded to therapy in November 2018. All the participants received individual therapy weekly. Additionally, apart from individual therapy, on November 25, 2018 the therapeutic group was launched, to which 22 women were enrolled on the recommendation of therapists and at will. The sessions of the group were held regularly once a week and its work was completed on the first of March 2019.
The experiment Group comprised 22 women (receiving group therapy) of the average age of 38 (aged from 26 to 48) who had in average children in the family, preceded in marriage from 3 to 23 years, divorced at the time of therapy initiation, and did not reside together with their partners; without a criminal record. All women were not housewives; the average wage they obtained was $\$ 7$ per hour (the minimum wage in Israel).

22 women were chosen to the control group (they received only individual therapy), which roughly coincided with the mentioned criteria.

As a result, the most reliable socio-demographic compliance was reached by 20 women: 10 in the experimental and 10 in the control group. The stating experiment was conducted in order to clarify the social and psychological state of women, who were in both (experimental and control) groups before the initiation of the therapy.

At this stage of the experiment the method of interviewing was used with the specially developed questionnaire of social adaptation and personal welfare, as well as observation as an additional method of information acquisition. The questionnaire developed with the participation of leading Israeli experts in social work, psychotherapy and supervision specially for the work of therapeutic centres, includes a system of questions that provide the ability to diagnose the state of women more comprehensively according to the principal criteria of social adaptation and personal welfare.

The questionnaire is multi-purpose and is always applied in the center's work on several stages of therapy. In our research, we conducted the survey twice: before starting the therapy and after its completion to analyze the effectiveness. It should be noted that this questionnaire is not only a means of diagnosis, but also an important therapeutic tool. During the conversation, a woman learns to show reflection, expands the possibilities of self-awareness, and starts being aware of the issues that were beyond the area of her perception. In addition, the client begins to see the progress, happening to her in comparison with the her state at beginning of therapy; she feels, where she has progressed, which sphere needs more efforts to make, what she has to aspire to further.

During the conversation under the questionnaire plan, a woman with the help of the therapist makes her self-evaluation from one to five points (where 1 is the lowest score of a factor, and 5 is the highest) in several important criteria concerning her socio-psychological state, which are both the efficiency criteria for the therapy. These criteria include: mindfulness, emotional stability, resource ability and functioning efficiency.

These criteria were highlighted on the basis of a number of indicators of social adaptation and personal welfare. As it was noted before, 
the woman who has undergone a traumatic experience of domestic violence is usually in a state of learned helplessness. She does not realize that the violence is illegitimate, she is inclined to justify the offender and blame himself, has low self-esteem, she contacts with the outside world from the position of a victim, she is incapable of independent actions to improve his life and social status, such woman is incapable of recognizing and, accordingly, control her feelings and does not know what she wants, often does not even separates the boundaries of her personality from a man, she suffers from codependence. As a consequence, the abused woman cannot function effectively as a mother, a family member, an employee, that is an authorized part of the society. The main criteria and indicators that were used as the basis of the questionnaire are the following:

- Mindfulness: how well the woman was aware and is aware now that she is a victim of domestic violence;

- Emotional Stability: whether a woman realize her personal value as a human being, whether she is self-conscious, aware of and experiencing her own dignity and inner strengths, whether she believes in her own abilities and whether she is satisfied with her state, whether she respects and values herself;

- Ability to use resources: whether she is able to see alternative options for the outcome from the same situation, and whether she is able to change her understanding of what is happening; whether she has information about her rights and where and what services can assist her in case of her rights breach;

- Efficiency of functioning: career efficiency; a role in the family as a mother; relations with other family members.

We assess the client's state by every aspect regarding the diagnosis of the dynamics of violent relations in a couple according to the following grayscale:

1 - no progress;

2 - poor progress;

3 - satisfactory progress;

4 - significant improvement;

5 - substantial progress.

Thus, the qualitative evaluation acquires its quantitative expression and becomes available for processing by using statistical methods and convenient comparison of the obtained results. The quantitative data has been input in SPSS22 computer program, handled statistically with the T-Test for couples and dispersion studies (comparison of averages).

As the questionnaire was designed for internal use in therapy centers and for preventing domestic violence as a multi-purpose therapeutic tool, we consider it advisable to review its reliability as a diagnostic tool.
In order to optimize the analysis of the obtained data, the following indices of each criterion were determined as: mindfulness; emotional stability; ability to use resource; efficiency of functioning.

The clients' answers to questions on each criterion of the questionnaire were checked for reliability according to the criterion of stability of test results (resistance is defined as the possibility to obtain the same data from the examined in different cases). This test is done in order to verify that all questions in each questionnaire table pertaining to each of the four checked criteria have an internal correlation (i.e. they are all united by a single subject) and the greater the correlation (connection) between the answers to the questions, the more reliable the index is [2, c. 91]. That is, with this method, we have tested whether we can consider the results of the questionnaire quite reliable for the formation of scientifically significant conclusions according to the results of the research. For this purpose, alpha Cronbach (Alpha Cronbach) indices were calculated for each of the probable ones. Wherein the rate of alpha which is less than 0.67 is not accepted (not reliable) [2, c. 92-98].

During the reliability analysis the indices of Alfa achieved 0.739 on the mindfulness index, alpha 0.76 for the emotional stability index. However, alpha performance by indexes of ability to use resources and performance efficiency were not achieved. In order to optimize indexes the procedure "If position is removed" was carried out. It allowed detecting the variables that worsen the intrinsic correlation. These were the points "the use of assertiveness" and "varied repertoire of behavior models" in the criteria "ability to use resources", as well as "the success of parental function" in the criteria "efficiency of functioning". After their removal it was possible to reach acceptable indicators of alpha reliability by the criteria of "ability to use resource" 0.73 , and alpha by the criterion "performance effectiveness" 0.69 . The generalized results of the reliability analysis are presented in the table below (Table 1).

\section{Index Reliability Analysis}

\begin{tabular}{|c|l|c|}
\hline $\mathbf{N}$ & \multicolumn{1}{|c|}{ Indices (criteria) } & $\begin{array}{c}\text { Alpha } \\
\text { Kronbach }\end{array}$ \\
\hline 1. & Mindfulness & 0,739 \\
\hline 2. & Emotional Stability & 0,76 \\
\hline 3. & Ability to Use Resources & 0,73 \\
\hline 4. & Efficiency of Functioning & 0,69 \\
\hline
\end{tabular}

The indices of mindfulness, emotional stability, ability to use resources and functioning have been built by using the averaging variables of each index in the SPSS program.

Accordingtotheresultsofthediagnostics, which was conducted at the stating stage of the experi- 
ment, the following data on the socio-psychological state of the studied women before the beginning of therapy in four parameters is obtained (Table 2).

The diagnostic data of the state of women affected by domestic violence and appealed for help to the therapeutic center at the stating stage of the experiment indicate that there is a relatively low level of average indicators of social adaptation and personal well-being for all four criteria: mindfulness - 36\% (1.8), emotional stability $35 \%$ (1.75), ability to use resources $-42 \%(2.1)$, efficiency of functioning $-51 \%$ (2.55).

In order to assess the effectiveness of social and psychological therapy for the prevention and elimination of domestic violence, a formative experiment was held, the purpose of which was to trace the dynamics of changes in the level of social adaptation and personal welfare of the women that were in therapy in the center according to four criteria. The individual therapy began on November 1, 2019, and was held with each client regardless of belonging to a check group or an experimental group. The sessions were conducted once a week and lasted for 50 minutes.

For the individual therapy, a psychodynamic approach with the use of elements of cognitive-behavioral therapy, narrative and imago therapy was used. During the social and psychological guidance and individual therapy the threat level was diagnosed, as well as the procedure of the debriefing, the joint search of internal and external resources, the choice of most effec- tive methods in each specific case of therapy and a number of therapeutic sessions during which there was an emotional response, search and consolidation of new behavioral strategies.

In the experimental group in addition to individual therapy the weekly work in a group took place. The purposes of the group work included the following: ensuring the participants with information on nature, motives, signs of domestic violence and means of resistance; creating a support network, increasing personal self-esteem, training soft skills, acquiring new knowledge and skills, etc. During the group work, the women received relevant information and discussed it. The following topics were discussed, like: Vicious Circle of Violence; Basis Injuries; Protective Mechanisms: why women remain in the relationship of domestic violence; Conflict. Emotional Control. Conflict Settlement; Changing Ways of Thinking. Pride and Self-esteem. Self Esteem.; Internal Power. Self-Awareness. Own Dignity; Motivation. Mercy to Others. Self-Mercy.

At the end of the experiment the assessment of the therapy effectiveness was performed by re-applying the social adaptation questionnaire and personal welfare. The results were presented as a table 3 .

The diagnostic data of the state after passing the social and psychological therapy suggest that as a result of the therapy there is a height on all criteria that were measured: mindfulness $89 \%$ (4.47), emotional stability - 86\% (4.31), ability to use resources - $88 \%$ (4.43), efficiency

Table 2

Averaged Data on the Socio-Psychological State of the Researched before the Therapy

\begin{tabular}{|l|c|c|c|c|}
\hline $\begin{array}{c}\text { Indices } \\
\text { (Criteria) }\end{array}$ & $\begin{array}{c}\text { Mindfulness Index } \\
(\boldsymbol{\alpha}-\text { Kronbach }=\mathbf{0 , 7 4 )} \\
\mathbf{n = 2 0}\end{array}$ & $\begin{array}{c}\text { Index of Emotional } \\
\text { Stability }(\boldsymbol{\alpha}=\mathbf{0 , 7 6 )} \\
\mathbf{n = 2 0}\end{array}$ & $\begin{array}{c}\text { Index of Ability } \\
\text { to Use Resource } \\
(\boldsymbol{\alpha}=\mathbf{0 , 7 3 )} \mathbf{n}=\mathbf{2 0}\end{array}$ & $\begin{array}{c}\text { Index of Efficiency } \\
\text { of Functioning } \\
(\boldsymbol{\alpha}=\mathbf{0 , 6 9 )} \mathbf{n = 2 0}\end{array}$ \\
\hline $\begin{array}{l}\text { Results before } \\
\text { the Therapy }\end{array}$ & 1,8 & 1,75 & 2,1 & 2,55 \\
\hline
\end{tabular}

Table 3

Averaged Data on Socio-Psychological State of the Investigated after Therapy

\begin{tabular}{|l|c|c|c|c|}
\hline $\begin{array}{c}\text { Indices } \\
\text { (Criteria) }\end{array}$ & $\begin{array}{c}\text { Mindfulness Index } \\
(\boldsymbol{\alpha}-\text {-Kronbach= 0,74) } \\
\mathbf{n = 2 0}\end{array}$ & $\begin{array}{c}\text { Index of Emotional } \\
\text { Stability }(\boldsymbol{\alpha}=\mathbf{0 , 7 6 )} \\
\mathbf{n = 2 0}\end{array}$ & $\begin{array}{c}\text { Index of Ability } \\
\text { to Use Resource } \\
(\boldsymbol{\alpha}=\mathbf{0 , 7 3 )} \mathbf{n = 2 0}\end{array}$ & $\begin{array}{c}\text { Index of Efficiency } \\
\text { of Functioning } \\
(\boldsymbol{\alpha}=\mathbf{0 , 6 9 )} \mathbf{n = 2 0}\end{array}$ \\
\hline $\begin{array}{l}\text { Results after } \\
\text { the Therapy }\end{array}$ & 4,47 & 4,31 & 4,43 & 4,19 \\
\hline
\end{tabular}

Averaged Indices Comparison on the Criteria Efficiency before and after the Therapy

\begin{tabular}{|l|c|c|c|c|}
\hline \multicolumn{1}{|c|}{ Indices (criteria) } & Before Therapy & After Therapy & t-Criterion & Sig Significance \\
\hline $\begin{array}{l}\text { Mindfulness Index } \\
(\alpha-\text {-Kronbach }=0,74) \mathrm{n}=20\end{array}$ & 1,8 & 4,47 & 18 & 0,00 \\
\hline $\begin{array}{l}\text { Emotional Stability Index } \\
(\alpha=0,76) \mathrm{n}=20\end{array}$ & 1,75 & 4,31 & 13,8 & 0,00 \\
\hline $\begin{array}{l}\text { Ability to Use Resource Index } \\
(\alpha=0,73) \mathrm{n}=20\end{array}$ & 2,1 & 4,43 & 16,8 & 0,00 \\
\hline $\begin{array}{l}\text { Efficiency of Functioning Index } \\
(\alpha=0,69) \mathrm{n}=20\end{array}$ & 2,55 & 4,19 & 9,7 & 0,00 \\
\hline
\end{tabular}


of functioning $-84 \%$ (4.19). All these results correspond to the high level of social adaptation and personal well-being on all four criteria.

To answer the question, whether the therapy in the center is effective and to what extent, and to determine which form of the therapy is the most successful, the thorough analysis of the data received during the stating and molding phases of the experiment was conducted.

To determine the therapy effectiveness of the center according to the criteria of mindfulness, emotional stability, ability to use resource and the efficiency of functioning, the differences in indices before and after the therapy were examined disregarding the type the therapy program (individual or group) with the use of the pair $t$-Student's Criterion [3, c. 51-53] to compare two dependent (paired) samples.

This criterion was chosen because in our case we have a dependent sample: evaluating indicators held with the same people at different times. The T-criteria for couples is suitable for continuous variables, which are the calculated by us indices. The results of the calculations with the use of the $t$-Student's Criterion are provided in the table 4 .

In this case, Sig (significance) is the probability of a random connection or $p$-level significance, i.e. the probability that the connection is accidental. The lower this index, the higher the statistical authenticity (significance) of connection is.

As we can see from the table, the average figures on all the indices were increased due to the results of therapy.

Thus, we can see a significant increase in all the four criteria for therapy in the center, which reliably proves the efficiency of the therapy carried out in the Center for women affected by domestic violence, regardless of the form of its implementation (i.e. individual or group therapy).
Conclusions. During the research, the characteristic of the work of the Regional Center for Therapy and Prevention of Domestic Violence in Beer Sheva City is described, as well as the existing protocol of social and psychological support of women affected by domestic violence, which includes: establishing a relationship of trust with a client; diagnosing the client's state and the level of danger and developing a woman's exit plan in the situation of danger; search for internal and external resources, which would allow a woman to go to the position of the figure (habilitation or empowerment); the client's motivation for further therapy. According to the results of the work we observe a significant growth on all four criteria of therapy in the center, which reliably proves the efficiency of the therapy carried out in the center for women who suffered from domestic violence, regardless of form of the therapy conduction (i.e. individual or group).

\section{REFERENCES}

1. Бек А. Когнитивная психотерапия расстройств личности / за ред. А. Фримена. Санкт-Петербург : Питер, 2002. 544 с.

2. Дубина И.Н. Математические основы эмпирических социально-экономических исследований: учебное пособие. Барнаул : Изд-во Алт. ун-та, 2006. 263 c.

3. Ивченко Г.И., Медведев Ю.И. Математическая статистика: учебник. Москва : Книжный дом «ЛИБРОKOM», 2014. 352 c.

4. Кочюнас Р. Психотерапевтические группы: теория и практика: учебное пособие. Москва : Академический Проект, 2000. 240 с.

5. Цвєтков М. Досвід соціально-психологічної терапії з профілактики та подолання насилля в сім'ях на прикладі Ізраїлю : автореф. маг. роб.. на здобуття ступеня магістра зі спеціальності 231 «Соціальна робота». Миколаїв, 2019. 17 с. 